\title{
EFFECT OF FERTILIZERS ON GRAIN YIELD AND GRAIN PROTEIN CONTENT OF WHEAT
}

\author{
M.A. HASAN ${ }^{1 *}$ and A.M.A. KAMAL ${ }^{2}$ \\ ${ }^{\prime}$ Department of Agronomy, Patuakhali Agricultural College, Patuakhali, Bangladesh \\ - Institute of Post Graduate Studies in Agriculture, Joydeopur, Gazipur, Bangladesh.
}

(Received: 28 May 1997; accepted: 07 November 1997)

\begin{abstract}
Studies were conducted at the Agronomy Field Laboratory of Bangladesh Agricultural University, Mymensingh from November 1994 to March 1995 in a sandy loam soil to investigate the effect of fertilization on grain yield and grain protein content of two varieties of wheat viz. Aghrani and Kanchan. Five fertilization treatments were used in this experiment. Kanchan was the superior variety which produced $2.99 \mathrm{t} / \mathrm{ha}$ grain yield, $3.79 \mathrm{t} / \mathrm{ha}$ straw yield and had $13.8 \%$ grain protein content. Aghrani had shorter field duration (107.0 days) than Kanchan (111.1 days). Fertilization treatments exhibited significant influence on all parameters studied. Urea in 4 splits + cowdung 10 t/ha produced the highest grain yield of 3.44 tha, straw yield of 4.21 tha and $14.1 \%$ grain protein content compared to inorganic fertilizers only producing lowest grain yield of $2.31 \mathrm{t} / \mathrm{ha}$, straw yield of $3.14 \mathrm{t} / \mathrm{ha}$ and $12.5 \%$ grain protein content. Field duration was longest ( 111.5 days) from the previous treatment and shortest ( 106.7 days) from inorganic fertilizers only. The results suggest that a higher dose of inorganic fertilizers with increased number of split applications of urea and organic manuring than the recommended dose of inorganic fertilizers may increase grain and straw yields and grain protein content of wheat under conditions of the experiment.
\end{abstract}

Key words: Cowdung, fertilizers, grain yield, protein, urea, wheat.

\section{INTRODUCTION}

Wheat which is the most important cereal in the world, accounts for one-third of the total cereal production. It is the second important cereal crop of Bangladesh. It was grown in 0.64 million hectares of land in 1992-93 which produced 1.18 million metric tons of wheat grain with an average yield of $1.85 \mathrm{t} / \mathrm{ha} .{ }^{1}$ Bangladesh runs short of food every year. In order to meet the food deficit and to cope with the demand for food for the increasing population, internal wheat production needs to be increased.

It appears that there is much scope for increasing yield to meet the ever rising food demand of the country. Modern wheat varieties need productive soil and optimum supply of growth factors for their proper growth and development. But continuous cropping reduces the nutrient content of most soils of Bangladesh. ${ }^{2}$ The use of chemical fertilizers in wheat without manures is depleting soil organic

"Present address: Department of Agronomy, Hajee Mohammad Danesh Agricultural College, Dinajpur-5200, Bangladesh. 
matter seriously and causing micronutrient deficiencies. ${ }^{3}$ However, application of organic manures in combination with fertilizers helps both in the proper nutrition of the crop plants and in maintaining the fertility of the soil. Moreover, organic manures will also help to solve the problem of micronutrient deficiency in the soil to some extent. The protein content of wheat is known to be influenced by cultivar, ${ }^{4}$ time of $\mathrm{N}$ application, ${ }^{5}$ nitrogen fertilization rate, ${ }^{6}$ method of $\mathrm{N}$ application ${ }^{7}$ and residual soil N. ${ }^{8}$ Hence, it appears that there is a need to find out a fertilizer management system using organic manures and inorganic fertilizers. The presentinvestigation is an attempt to study the effect of inorganic fertilizers alone and in combination with organic manure with increased number of split applications of urea on grain yield and grain protein content of wheat.

\section{METHODS AND MATERIALS}

Studies were conducted at the Agronomy Field Laboratory of Bangladesh Agricultural University, Mymensingh from November 1994 to March 1995 in a sandy loam soil. The land was previously used for wheat and then fallow. The treatments were laid out in a split-plot design with three replications assigning fertilization in the main plot and variety in the subplot at random. The size of each unit plot was $5 \mathrm{~m} \times 4 \mathrm{~m}$. Two wheat varieties viz. Aghrani and Kanchan and five fertilizations: $\mathrm{F}_{1}$ (control)-inorganic fertilizers only (IF) as recommended by BARI, ${ }^{9}$ with urea in two splits (basal and 27 DAS), $F_{2}-$ IF with high yield target (HT), with urea in three splits (basal, 27 and $55 \mathrm{DAS}$ ) + cowdung 5 t/ha, $\mathrm{F}_{3}-\mathrm{HT}$ with urea in four splits (basal, 27, 55 and $75 \mathrm{DAS}$ ) + cowdung 5 t/ha, $\mathrm{F}_{4}$ - HT with urea in three splits (basal, 27 and 55 DAS) +cowdung 10 t/ha, $\mathrm{F}_{5}$ - HT with urea in four splits (basal, 27, 55 and 75 DAS) + cowdung 10 t/ha were used as treatments. Urea $(220 \mathrm{~kg} / \mathrm{ha})$, triple superphosphate (180 kg/ha), muriate of potash (50 kg/ha) and gypsum (120 kg/ha) were applied as per recommended dose. Topdressing of urea was carried out as per experimental treatments. The crop was irrigated twice during the growth period on 27 December 1994 and 12 February 1995. Weeding was carried out twice prior to first and second irrigations. Crop of each plot was harvested separately. Ten plants were selected at random from four $0.25 \mathrm{~m}^{2}$ sample areas in each plot harvested separately. Total nitrogen content of wheat grains was determined by micro-Kjeldahl method. ${ }^{10}$ The protein content was determined from per cent total nitrogen multiplied by 5.85 . Statistical significance was determined by the LSD Test.

\section{RESULTS AND DISCUSSION}

The results showed that Kanchan $(103.0 \mathrm{~cm})$ was taller than Aghrani $(98.5 \mathrm{~cm})$ (Table 1). That variety may differ for plant height was also reported by Shrestha. ${ }^{11}$ The shortest plants $(96.8 \mathrm{~cm})$ resulted from $\mathrm{F}_{1}$, whereas the tallest plants $\left(106.0 \mathrm{~cm}\right.$ ) were obtained from $F_{5}$ (Table 2). The interaction effect of variety and fertilization on plant height was statistically significant (Table 3 ). 


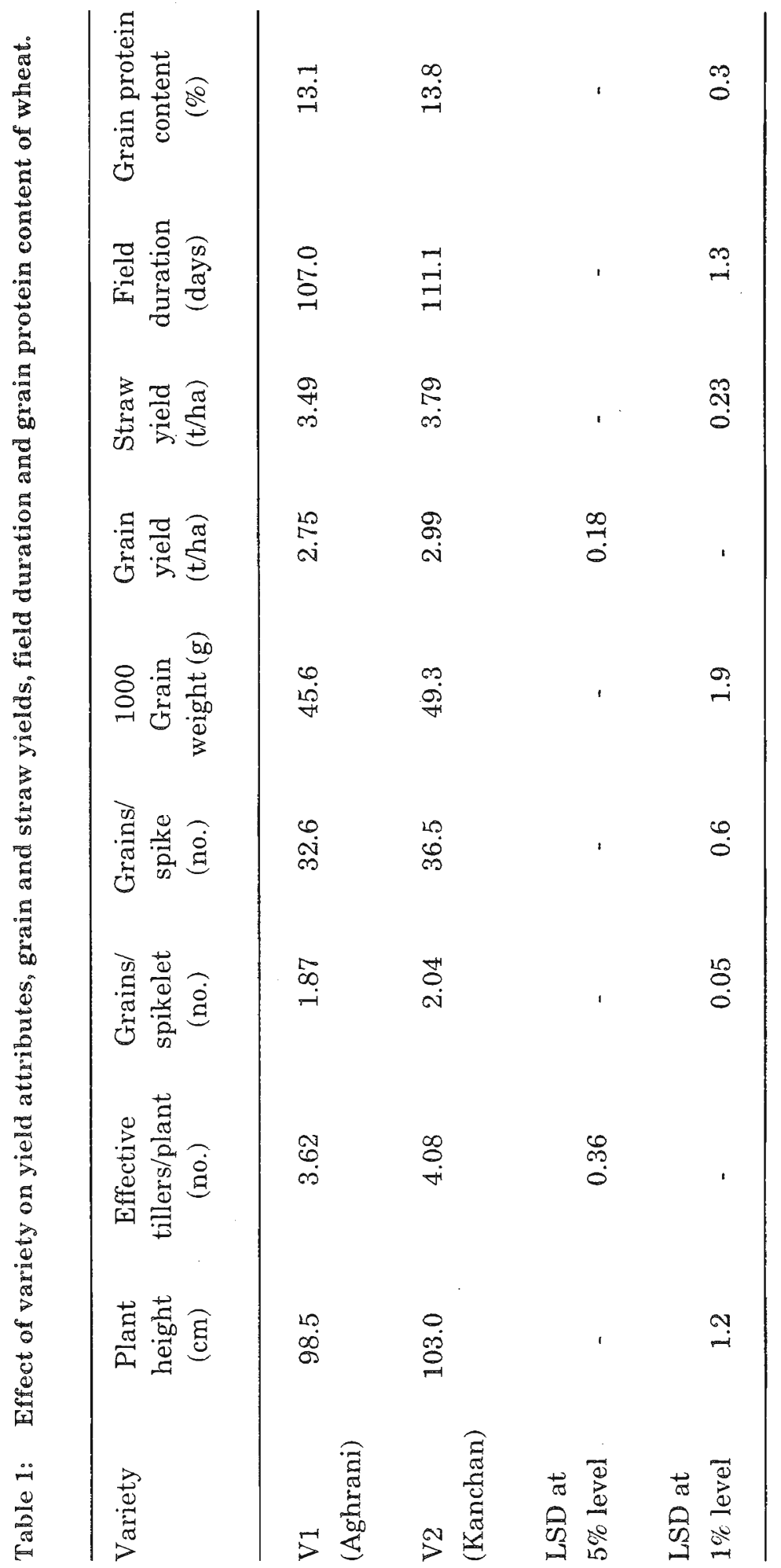




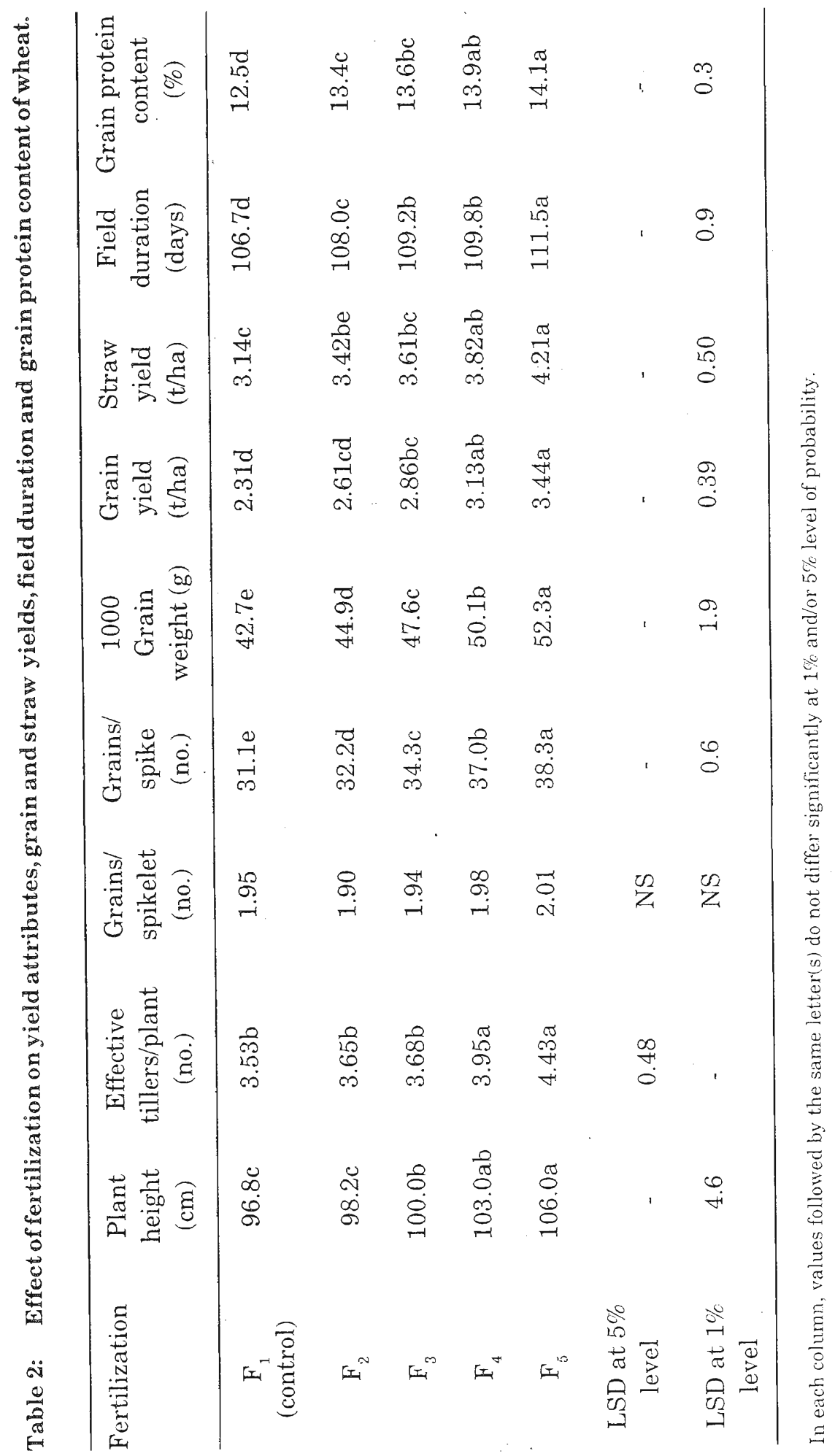


Of the two varieties, Kanchan produced higher number of effective tillers per plant (4.08) (Table 1), the lowest number (3.53) being produced by $\mathrm{F}_{\text {, treatment }}$ and the highest number (4.43) by $F_{5}$ treatment (Table 2).

The results showed that a treatment combination of high inorganic fertilization with $10 \mathrm{t}$ cowdung/ha +4 split applications of urea produced most favourable influence on number of effective tillers/plant. It was found that Kanchan produced more grains per spikelet (2.04) than Aghrani (1.87) (Table 1). The effect of fertilization on number of grains per spikelet was not statistically significant (Table 2). But the interaction effect of variety and fertilization on number of grains per spikelet was significant and number of grains per spikelet due to the interaction effect ranged from 1.82 to 2.13 (Table 3 ). The number of grains/spike in Kanchan (36.5) was higher than in Aghrani (32.6) (Table 1). A similar result was also reported by Ceapoiu et al. ${ }^{12}$ The lowest number of grains/ spike (31.1) was obtained from $\mathrm{F}_{1}$ treatment and the highest number (38.3) from $\mathrm{F}_{5}$ treatment (Table 2). The interaction effect of variety and fertilization on grains/spike was significant (Table 3). The number of grains/spike due to different interactions ranged from 28.9 to 40.4 . The weight of 1000 grains of Kanchan (49.3 g) was higher than that of Aghrani ( $45.6 \mathrm{~g}$ ) (Table 1). A similar result was also reported by Shrestha. ${ }^{11}$ The lowest weint of 1000 grains $(42.7$ g) was obtained from control $\left(F_{1}\right)$ and the highest weight $(52.3 \mathrm{~g})$ from $F_{5}$ treatment (Table 2).

Table 3: Effect of interaction of variety and fertilization on plant height, grains/spikelet and grains/spike of wheat.

Treatment Plantheight (cm) Grains/spikelet(no.) Grains/spike (no.)

$\begin{array}{llllllll}\text { Variety } & \mathrm{V}_{1} & \mathrm{~V}_{2} & \mathrm{~V}_{1} & \mathrm{~V}_{2} & \mathrm{~V}_{1} & \mathrm{~V}_{2}\end{array}$

Fertilization

\begin{tabular}{ccccccc}
\hline $\mathrm{F}_{1}$ & $95.0 \mathrm{~h}$ & $98.7 \mathrm{e}$ & $1.86 \mathrm{e}$ & $2.03 \mathrm{~b}$ & $28.9 \mathrm{~h}$ & $33.3 \mathrm{ef}$ \\
$\begin{array}{c}\text { control) } \\
\mathrm{F}_{2}\end{array}$ & $95.7 \mathrm{gh}$ & $100.7 \mathrm{~d}$ & $1.82 \mathrm{e}$ & $1.97 \mathrm{bc}$ & $30.5 \mathrm{~g}$ & $34.0 \mathrm{de}$ \\
$\mathrm{F}_{3}$ & $97.0 \mathrm{fg}$ & $103.3 \mathrm{c}$ & $1.93 \mathrm{~cd}$ & $1.96 \mathrm{c}$ & $33.2 \mathrm{f}$ & $35.4 \mathrm{c}$ \\
$\mathrm{F}_{4}$ & $99.3 \mathrm{de}$ & $105.7 \mathrm{~b}$ & $1.84 \mathrm{e}$ & $2.12 \mathrm{a}$ & $34.5 \mathrm{~d}$ & $39.5 \mathrm{~b}$ \\
$\mathrm{~F}_{5}$ & $105.3 \mathrm{~b}$ & $107.3 \mathrm{a}$ & $1.88 \mathrm{de}$ & $2.13 \mathrm{a}$ & $36.1 \mathrm{c}$ & $40.4 \mathrm{a}$ \\
\hline LSD at 1\% level & \multicolumn{7}{c}{1.5} & \multicolumn{2}{c}{0.06} & & 0.7 \\
\hline
\end{tabular}

In each column, values followed by the same letter(s) do not differ significantly at $1 \%$ and/or $5 \%$ level of probability. 
The results showed that Kanchan produced higher grain yield (2.99 t/ha) than Aghrani (2.75 t/ha) (Table 1). Higher grain yield from Kanchan was the result of superior performance of all yield components from this variety. The lowest grain yield (2.31 t/ha) was produced by $\mathrm{F}_{1}$ treatment and the highest ( $3.44 \mathrm{t} / \mathrm{ha}$ ) by $\mathrm{F}_{5}$ treatment (Table 2 ). This higher grain yield from $\mathrm{F}_{5}$ treatment was attributable to higher number of effective tillers, grains/spike and 1000 grain weight from this treatment, the results being similar to those of Konov et al. ${ }^{13}$ Mehta \& Daftardar. ${ }^{14}$ Kanchan produced higher straw yield (3.79 t/ha) than Aghrani (3.49 t/ha) (Table 1). Higher plant height and more tillers of Kanchan possibly contributed to higher straw yield of this variety than Aghrani. Similar effect of cultivar on straw yield of wheat was reported by Sharma et al. ${ }^{15}$ The lowest straw yield ( $3.14 \mathrm{t} / \mathrm{ha}$ ) was produced by $F_{1}$ treatment and the highest (4.21 t/ha) by $\mathrm{F}_{5}$ treatment (Table 2 ). This result was partially similar to the result of Singh et al. ${ }^{16}$ Field duration of Kanchan (111.1 days) was higher than that of Aghrani (107.0 days) (Table 1). The duration was significantly the shortest (106.7 days) from $\mathrm{F}_{1}$ treatment and the longest (111.5 days) from $\mathrm{F}_{5}$ treatment (Table 2). From the results, it can be said that the crop took more time to mature as fertilization with organic manuring increased with increasing split application of urea.

There was a significant difference between the varieties for grain protein (Table 1). It was found that grain protein content of Kanchan (13.8\%) was higher than that of Aghrani (13.1\%) (Table 1). That varieties may differ for grain protein content was also reported by Nedelciue et al. ${ }^{17}$ The effect of fertilization on grain protein content was significant (Table 2). Grain protein content from different treatments ranged from $12.5 \%$ to $14.1 \%$ (Table 2 ). Significantly lowest grain protein content resulted from $\mathrm{F}_{1}$ treatment and the highest from $\mathrm{F}_{5}$ treatment. The grain protein contents from $\mathrm{F}_{4}$ and $\mathrm{F}_{5}$, from $\mathrm{F}_{3}$ and $\mathrm{F}_{4}$, and from $\mathrm{F}_{2}$ and $\mathrm{F}_{3}$ did not differ significantly (statistically). These results suggest that application of cowdung as organic manure up to 10 t/ha together with high level of inorganic fertilization can increase grain and straw yieids and grain protein content of wheat over recommended dose of inorganic fertilizers alone under conditions of the experiment.

\section{References}

1. BBS. (1994). Statistical pocket book of Bangladesh. Stat. Div. Ministry of Planning, Govt. People's Repub. Bangladesh, Dhaka. 152 p.

2. Saunders D.A. (1990). Report on the On-Farm survey Dinajpur District farmer's practices and problems, and their implication. Monograph No. 6. Wheat Research Centre, BARI, Nashipur, Dinajpur. 
3. Islam M.S. (1988). Micronutrient studies in soils and crops of Bangladesh. Paper presented at the meeting on "Policy Measures in Micronutrient Deficiency". on 28 April, BARC, Dhaka.

4. Johnson V.A. \& Mattern P.J. (1993). Improvement of the nutritional quality of wheat through increased protein content and improved amino acid balance. Final Report, Univ. Nebraska Lincoln. USAID contract no. AID/csd-1208 and AID/ta-c-c-1093. Agronomy Journal 85: 1023-1028.

5. Vaughan B., Westfall D.G. \& Barbarick K.A. (1990). Nitrogen rate and timing effects on winter wheat grain yield, grain protein and economics. Journal of Production Agriculture 3: 324-328.

6. Memon G.H. \& Jamro G.H. (1988). Influence of nitrogen fertilization on grain protein content and NPK content of straw in late sown wheat (T. aestivum L. ). Pakistan Journal of Scientific and Industrial Research 31: 649-650.

7. Cochran V.L., Warner R.L. \& Papendick R.I. (1978). Effect of N depth and application rate on yield, protein content and quality of winter wheat. Agronomy Journal 70: 964-968.

8. Olsen R.A., Frank K.D., Deibert E.J., Dreier A.F., Sander D.H. \& Johnson V.A. (1976). Impact of residual mineral $\mathrm{N}$ in soil on grain protein yields of winter wheat and corn. Agronomy Journal 68: 769-772.

9. BARI (1990). Means of profitable wheat cultivation. (In Bengali). Wheat Research Centre. Bangladesh Agricultural Research Institute. Nashipur, Dinajpur. pp. 1-11.

10. Piper C.S. (1950). Soil and plant analysis. Adelaide Univ. Press, Australia.

11. Shrestha S. (1991). Quantitative analysis of matured plants of introduced wheat cultivars of Nepal. Field Crop Abstracts 44(1): 4.

12. Ceapoiu N., Saulescu N.N., Eustatiu, N., Tapo C., Ittu G., Negulescu F. \& Ionescucojocaru M. (1984). Fundulea-29 winter wheat. Field Crop Abstracts $37(6): 394$.

13. Konov V., Petrov P., Enikov Z.H. \& Dekov D. (1986). Determination of cumulative effect of organic manures and mineral fertilizers on grain quality of wheat. Field Crop Abstracts 39(8): 635. 
14. Mehta S.A. \& Daftardar S.Y. (1984). Effect of anaerobically prepared wheat straw compost and city garbage compost on yield and $\mathrm{N}$ and $\mathrm{P}$ uptake by wheat. Field Crop Abstracts 37(8): 640.

15. Sharma K.N., Bhandari A.L., Rana D.S., Sodhi J.S. \& Kapur M.L. (1990). Nitrogen requirement of wheat ( T. aestivum L. ) varieties as influenced by date of sowing. Field Crop Abstracts 43(3): 205.

16. Singh V., Ydav S.N.R. \& Singh M.M. (1975). Responce of Kalyansona to levels of fertility and method of fertilizer application. Field Crop Abstracts $27(1): 4$.

17. Nedelciue C. Patrascoiv C. \& Nedelcicie M. (1986). Quality of the harvest in some wheat varieties grown under irrigation in the South East of Oltenia. Field Crop Abstracts 39(10): 30. 